\title{
Association between self-reported health and sociodemographic characteristics with cardiovascular diseases in adults
}

\author{
Associação entre autopercepção de saúde e características sociodemográficas \\ com doenças cardiovasculares em indivíduos adultos
}

Asociación entre la autopercepción de salud y las características sociodemográficas con relación a las enfermedades cardiovasculares en individuos adultos

Guilherme Oliveira de Arruda ${ }^{1}$, Aliny de Lima Santos², Elen Ferraz Teston², Hellen Pollyanna Mantelo Cecilio ${ }^{3}$, Cremilde Aparecida Trindade Radovanovic ${ }^{4}$, Sonia Silva Marcon ${ }^{5}$

${ }^{1} \mathrm{PhD}$ Student, Graduate Program in Nursing, State University of Maringá, Maringá, PR, Brazil.

${ }^{2}$ PhD Student, Graduate Program in Nursing, State University of Maringá, Maringá, PR, Brazil.

${ }^{3}$ Assistant Professor, University of Paraná, Paranavaí Campus, PR, Brazil.

${ }^{4}$ Adjunct Professor, State University of Maringá, Maringá , PR, Brazil.

${ }^{5}$ Professor, State University of Maringá, Maringá, PR, Brazil.

\section{ABSTRACT}

Objective: To assess the association of sociodemographic and self-rated health in the presence of cardiovascular diseases and the association of this perception with the type of disease. Methods: A cross-sectional population survey study carried out with 1,232 individuals aged between 20 and 59 years of both genders living in the metropolitan region of Maringá-PR. Data were analyzed using multiple and simple logistic regression. Results: In multivariate analysis, the age range and self-rated health were associated with cardiovascular disease, and in the univariate analysis self-rated regular health was associated with arterial hypertension, while self-rated poor health was associated to heart failure, stroke, and to acute myocardial infarction (heart attack). Conclusion: The differences in association of self-rated health with these diseases can indicate how individuals with certain characteristics cope with the disease, allowing for more individualized and specific health care.

\section{DESCRIPTORS}

Cardiovascular Diseases; Risk Factors; Prevalence; Population Surveys; Nursing. 


\section{INTRODUCTION}

Chronic non-communicable diseases (NCDs) have generated loss in quality of life with a high degree of limitation in work and leisure activities, economic impacts and a high number of premature deaths ${ }^{(1-2)}$. For the next few decades, there are global growth projections of NCDs, particularly cardiovascular diseases (CVDs), which currently are the most common causes of morbidity and taken together, the leading causes of mortality worldwide ${ }^{(3)}$.

Annually, ischemic heart disease, stroke and high blood pressure are responsible for 15.9 million deaths worldwide $^{(3)}$. In 2008 specifically, CVDs accounted for $34 \%$ of the adult population deaths and $40.8 \%$ of deaths in individuals aged 60 years or more. Among its main subgroups, cerebrovascular disease and ischemic heart disease totalled more than $60 \%$ of deaths in the country ${ }^{(4)}$. This scenario requires that professionals and health managers acquire the ability to organize and implement health care corresponding to the multifactorial genesis, experience and aggravating character of CVDs.

Recent studies have shown the prevalence, associated risk factors and socioeconomic characteristics - age, gender and economic class - with CVD diagnosis ${ }^{(5)}$. However, little has been investigated on the association of the perception that individuals have of their health with $\mathrm{CVD}^{(6)}$. This perception is a useful indicator of health care needs, as well as being highly sensitive with respect to social and organic factors that determine problems and inequalities in health. In the the literature, it has been observed that most research has mainly focused on the elderly population, the factors related to self-perception, and regional differences ${ }^{(7)}$.

However, it is also observed that self-rated health has an important relationship with the agglomeration of risk factors for CVD and is different in the presence or absence of disease, especially those which are chronic and non-communicable ${ }^{(8-9)}$. There is also association to morbidity and use of services because of the way the person evaluates their health condition in itself indicates the presence of disease (with or without diagnosis by a health professional) and even the impact it can generate on their physical, mental and social well-being ${ }^{(10)}$. Thus, considering that self-perception is an important marker of cardiovascular health ${ }^{(9)}$, the identification of the disease may not only favor the implementation of care, but also its management.

Self-awareness can signal the way a person's life is influenced by an experienced problem and also their healthy living concepts ${ }^{(11)}$. Taking into account that health professionals and nurses can identify the self-perception of individuals with CVD in everyday care, one can also find health needs, the level of adherence to preventive practices and promotion or treatment, the presence of disease, and the risk of mortality ${ }^{(6)}$; any of which may determine the practices to be implemented in monitoring health status and qualify the care management.

Thus, by providing an ease for raising this variable with the individuals, it is noted that through self-rated health it is possible to obtain important information about the population, especially because it has been identified by significant association between this variable and the different health indicators ${ }^{(6)}$. Contemplating the scarcity of studies evaluated in general with the association of sociodemographic characteristics and self-perception of health with CVD raises the following research questions: Is there an association of sociodemographic characteristics and self-rated health with the presence of cardiovascular disease in adults? If self-rated health is associated with CVDs in general, are there differences in the types of CVDs?

Consequently, in order to contribute to non-reductive attention that corresponds to the characteristics and selfrated health of adults affected by CVDs, the present study aimed to analyze the association of sociodemographic characteristics and self-rated health in the presence of cardiovascular disease, and the association of self-rated health with the type of cardiovascular disease.

\section{METHOD}

The study is part of a larger research entitled, " $A$ population survey on the prevalence of risk factors and protection for cardiovascular disease in the metropolitan region of Maringa," financed by the Foundation of Araucaria Support for Scientific and Technological Development of the State of Paraná - Notice Search for SUS / 2010 Protocol - 19510. This cross-sectional, descriptive-analytic population-based study was conducted with adults aged 20 to 59 years, of both genders andresidents of three municipalities in the metropolitan region of Maringa (MRM): Maringá, Sarandi and Paiçandu. The originality of the study is therefore noteworthy because it is a household population-based survey of adult residents in the metropolitan area of southern Brazil and took the relationship of sociodemographic and self-related health perception of CVD as its main object of study.

Maringa is located in the north-central mesoregion of Paraná state and has established itself as the main center of the MRM, with a history of development and metropolis processes and different urbanization than other northern regions of Paraná, and even from other municipalities in the MRM like Sarandi and Paiçandu ${ }^{(12)}$. In the period of this study, the city of Maringa had 357,077 inhabitants; Sarandi, 82,347, and Paiçandu, 35,941. The three municipalities had a population of around 475,365 inhabitants, of whom 256,459 were adults aged 20 to 59 years.

The following inclusion criteria were adopted for the selection of individuals: to be aged between 20 and 59, be present at home at the time of data collection, understand the purpose of the study and the questions of the data collection instrument, and also not have hearing difficulties and / or speech that prevented communication. We used a systematic random sampling technique.

The sample size for each municipality was set independently, based on the formula: $\mathrm{n}=Z^{2} \mathrm{PQ} / \mathrm{d}^{2}$, where $\mathrm{n}=$ minimum sample size; $Z$ = reduced variable; $P$ = probability of finding the studied phenomenon. We adopted the value of $50 \%$ for the probability of the event being found, $5 \%$ 
estimation error (d), 95\% confidence and accuracy level of the sample, $Z=1.96$ (normal standard deviation), taking as a basis a level of significance expressed by $\alpha=0.05$ (or $5 \%)$ and $Q=1-0.5$, which in turn expressed the estimated proportion of the population that does not correspond to the existence of the studied event. For the draw, 10\% was added to the number of individuals, considering any losses that might occur related to completing the data collection instrument. Thus, the present study included 1,232 adults of both genders, with 431 from Maringa, 416 from Paiçandu and 385 from Sarandi.

The selection of subjects to be included in the study was carried out with unity reference to the Demographic Expansion Areas (AED). According to the Brazilian Institute of Geography and Statistics (IBGE) at the time, Maringa had 14 AED, Sarandi had 4, and Paiçandu one. We used systematic sampling strategy with probability proportional to the size of the sector, and drew the beginning of the route point and the initial corner of each sector, always walking clockwise. A resident individual was systematically approached with predefined range in the fourth house on the right side of the street. When there weren't individuals in the age group of interest residing at home, we went to the following household as the predefined systematic interval. When there was more than one adult in the household, a simple draw was conducted between them.

Interviews were conducted mostly during the weekdays in the afternoon, between the months of September 2010 and July 2011, using an instrument containing parts of the individual questionnaire called, "Household Survey About Risk Behavior and Morbidity Diseases and Noncommunicable Diseases ${ }^{(13)}$." The instrument was previously evaluated in a pilot study with a resident population close to the State University of Maringá (UEM), and defects/flaws in the understanding of the questions were corrected. For the stratification of individuals into the economic classes A, B, C, D and E, the Brazil Economic Classification Criteria by the Brazilian Association of Research Companies - ABEP-2010 was used, and is based on the level of the head of the household's education and on the possession/ ownership of certain household items ${ }^{(14)}$.

The dependent variable was the previously referred to CVDs (hypertension, acute myocardial infarction, heart failure, stroke and angina), categorized as yes $(Y=1)$ and no $(Y=0)$. This variable was treated in two different ways: first, the presence or absence of any CVD was considered; subsequently the dependent variable (CVD) was divided into five, by analyzing each CVD separately in association with self-rated/perceived levels of health. The independent variables were the demographic and socioeconomic characteristics (male and female, classified aged ranges 20-29, 30$39,40-49$ and 50-59 years, skin color as white or non-white, marital status being with or without companion, economic class defined as A, B, C, D or E), and self-rated health ${ }^{(15)}$ (excellent, very good, good, fair or poor), for which respondents were asked to take people the same age as them as a health reference to compare their perception (comparative definition).
A descriptive analysis of data was performed and then an association of independent variables with the variable of interest (CVD) was checked by univariate analysis (chisquare test). In the modeling process, the variables were included in the multiple logistic model unconditioned, according to the lower value of $p$, considering for both $p$ $<0.20$, as the choice of $p<0.05$ is very strict and so can exclude important variables of the final model as pointed out in the literature ${ }^{(16)}$. When working with the multicategoric independent variables (age, economic status and self-rated health), where the proportion of individuals with cardiovascular disease was lower was taken as the reference category for the tests. Univariate analysis using simple logistic regression was used to check the association of self-rated health with each CVD, highlighting the $\mathrm{p}$ values for each category of self-perception.

The measure of association used was the odds ratio (OR) with 95\% confidence interval and the level of significance set at $\mathrm{p}<0.05$ for all tests. The Hosmer-Lemeshow test was used to check the adjustment of the multiple logistic regression model, taking the adjusted model as the null hypothesis and the unadjusted model as the alternative hypothesis. Therefore when $\mathrm{p}>0.05$ it the null hypothesis is not rejected, thereby accepting the adjusted model, in which the closer to 1.0 the $\mathrm{p}$-value is, the better the quality the adjustment of the model.

The project was approved by the Standing Committee on Ethics in Human Research EMU-COPEP / EMU (Opinion No.173/2010 and No.546/2011). All participants signed two copies of the Informed Consent (IC) form.

\section{RESULTS}

The largest proportion of individuals were females $(72.2 \%)$ with a mean age of 40.3 years (mean $=39.1, \mathrm{SD}$ $=12.3$ for men and mean $=40.9, \mathrm{SD}=11.7$ for women), and the predominant age group was 50-59 years (28.4\%), white $(75.4 \%)$, with a partner $(66.2 \%)$ and economic class C (56\%). As for self-rated health, the highest level was good at $42.9 \%$, followed by fair/average (26.9\%), very good (11.2\%), excellent (10.3\%) and poor/bad (8.7\%). The overall self-rated prevalence of CVD was $26.8 \%$, taking only the number of respondents with the presence or absence of CVD ( $\mathrm{n}=1179)$. Alone, CVD presented in the following order of importance according to their prevalence: hypertension (21.6\%), angina (5.0\%), heart failure (3.6\%), acute myocardial infarction (3.5\%) and stroke (3.2\%).

When we studied the association of sociodemographic characteristics and self-rated health with the presence of CVD, univariate analysis showed that the only variable that was not associated was skin color, and the others presented association with CVD in the following order of significance: age, self-rated health, marital status/living situation, economic class and gender (Table 1).

In multivariate analysis, it was found that the age and self-rated health were significantly associated with CVD, independently of other variables included in the model, which in turn were not adjusted. The age groups were significantly associated with CVD, with the odds ratio gradually 
Table 1 - Univariate analysis of the association of sociodemographic and self-rated health variables with cardiovascular disease - Metropolitan Region of Maringa, PR, 2012.

\begin{tabular}{|c|c|c|c|}
\hline \multirow{2}{*}{ Variable $^{\#}$} & \multicolumn{2}{|c|}{ Cardiovascular Diseases } & \multirow[b]{2}{*}{$p^{*}$} \\
\hline & $\mathbf{n}$ & $\%$ & \\
\hline \multicolumn{4}{|l|}{ Gender $(n=1179)$} \\
\hline Male & 77 & 23.4 & \multirow{2}{*}{0.029} \\
\hline Female & 330 & 26.8 & \\
\hline \multicolumn{4}{|l|}{ Age Range $(n=1168)$} \\
\hline 20 to 29 years & 30 & 10.6 & \multirow{4}{*}{$<0.001$} \\
\hline 30 to 39 years & 44 & 17.9 & \\
\hline 40 to 49 years & 88 & 28.9 & \\
\hline 50 to 59 years & 325 & 48.8 & \\
\hline \multicolumn{4}{|l|}{ Skin color $(n=1130)$} \\
\hline White & 244 & 28.7 & \multirow{2}{*}{0.615} \\
\hline Not white & 320 & 27.1 & \\
\hline \multicolumn{4}{|c|}{ Conjugal Situation $(n=1177)$} \\
\hline With Partner & 92 & 23.0 & \multirow{2}{*}{0.007} \\
\hline Without Partner & 329 & 30.5 & \\
\hline \multicolumn{4}{|c|}{ Economic Class $(n=1169)$} \\
\hline Class A & 3 & 9.1 & \multirow{5}{*}{0.019} \\
\hline Class B & 102 & 25.3 & \\
\hline Class C & 201 & 30.4 & \\
\hline Class D & 21 & 29.6 & \\
\hline Class E & 328 & 0.1 & \\
\hline \multicolumn{4}{|c|}{ Self-rated Health $(n=1158)$} \\
\hline Excellent & 19 & 16.1 & \multirow{5}{*}{$<0.001$} \\
\hline Very Good & 24 & 18.8 & \\
\hline Good & 111 & 22.3 & \\
\hline Regular/Average & 125 & 40.1 & \\
\hline Poor & 327 & 46.6 & \\
\hline
\end{tabular}

\# Considering only the valid data. ${ }^{*}$ Chi-square test.

increasing with age being that 7.60 indicated the most likely health levels were associated with CVD, with greater odds to report CVD in the range of 50 to 59 years, compared to ratio for those with a poor level, taking as reference the 20-29 years. It was also reported that the worst self-rated excellent self-rated category (Table 2).

Table 2 - Multiple logistic regression analysis for the association of the variables of age, marital status, economic class, gender and self-rated health with cardiovascular disease - Metropolitan Region of Maringa, PR, 2012.

\begin{tabular}{|c|c|c|c|c|}
\hline Variable & $\mathrm{OR}_{\text {adjusted }}{ }^{\#}$ & IC95\% OR adjusted $_{\text {. }}$ & $p^{*}$ variable & $p^{*}$ category \\
\hline \multicolumn{5}{|l|}{ Age Range } \\
\hline 20 to 29 years & 1 & - & \multirow{4}{*}{$<0,001$} & - \\
\hline 30 to 39 years & 1.62 & $0.95-2.75$ & & 0.074 \\
\hline 40 to 49 years & 3.01 & $1.86-4.87$ & & $<0.001$ \\
\hline 50 to 59 years & 7.60 & $4.78-12.1$ & & $<0.001$ \\
\hline \multicolumn{5}{|l|}{ Conjugal Situation } \\
\hline With Partner & \multirow{2}{*}{1.21} & \multirow{2}{*}{$0.88-1.68$} & \multirow{2}{*}{0.235} & - \\
\hline Whithout Partner & & & & - \\
\hline
\end{tabular}




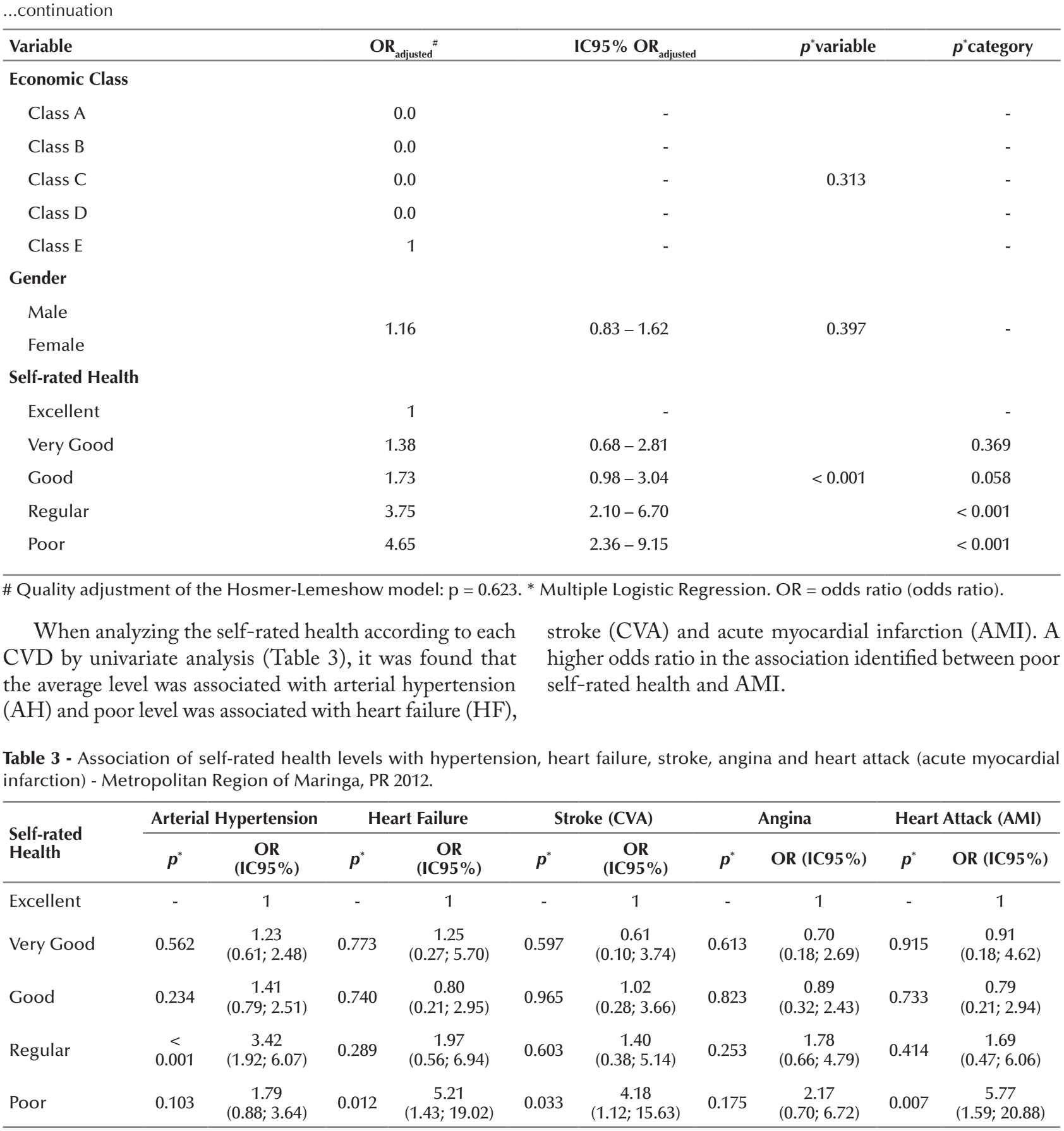

$\mathrm{OR}=$ odds ratio (odds ratio). ${ }^{*}$ Chi-square test.

\section{DISCUSSION}

Despite some methodological limitations, such as no sample stratification by gender and age (which would require more time and financial resources for data collection), and the fact that the study participants were selected from those present in the household resulting in a sample composed mostly of women, it can be stated that the results are valid and they do not differ much from what has been found in other Brazilian cities in terms of sociodemographic characteristics and self-rated health.

The composition of the sample studied is similar to other studies in relation to the predominance of women, white skin color and marital status with partner; however, it is notewor- thy that the proportion of female respondents in this study $(72.2 \%)$ is considerably higher than in others, which were conducted with individuals aged between 15 and 59 years, and 20 years or older, respectively ${ }^{(5,17)}$. There was also a higher proportion of persons aged between 50 and 59 years, which is especially similar to the study conducted in Pelotas in which older people comprised the majority of the sample $\mathrm{e}^{(5)}$.

As for the economic class, the prevalence of $\mathrm{C}$ stratum may have been influenced by the conformation called coreperiphery, centered in the city of Maringa, with the municipalities of Sarandi and Paiçandu forming the peripheral regions of the MRM where there are proportionally more people living with a lower economic class ${ }^{(12)}$. 
A considerable proportion of individuals perceived their health as good (41.8\%), corroborating another study with adults, adolescents and the elderly ${ }^{(6)}$. However, it should be noted that self-rated health is directly influenced by age, becoming an inverse relationship in which the older selfrate their health as worse ${ }^{(4)}$.

The association of older age groups with the occurrence of CVD is already known and mainly explained by biological predisposition to CVD inherent to aging, regardless of other risk factors ${ }^{(8,17)}$. Thus, this variable has been considered a confounding factor in conceptual models that attempt to explain the occurrence of CVD from different factors, predominantly cardiovascular risk factors already known in the literature ${ }^{(18)}$.

The prevalence of fair / poor self-rated health was higher than in a population-based study conducted in Porto Alegre, which reported a prevalence between 20.5 and $27.8 \%$ among a similar age group ${ }^{(19)}$. It should be noted that other factors have been shown to be associated with selfperception of regular / poor health, for example female ${ }^{(19)}$, lower economic class ${ }^{(6)}$ and a frequency of greater than four visits per year to doctors ${ }^{(19)}$.

With respect to CVD, the prevalence of $26.8 \%$ was higher than that found in a study by the Ministry of Health in 26 Brazilian cities, which found a mean prevalence of $21.6 \%{ }^{(19)}$. However, it was lower than that found in a study conducted in Florianopolis with adults aged 20 to 50, in which the prevalence reached $40.1 \%{ }^{(20)}$. Internationally, it appears that the prevalence of hypertension in Canada was 19.5\%, lower than in the US (29\%) and England (30\%) ${ }^{(21)}$. It should be noted that in 2000 , the prevalence of hypertension in the world population was $25 \%$ and the estimate for 2025 is $29 \%^{(22)}$.

As for the association between CVD and self-rated health, it was observed that it was present in all the diseases addressed, except angina. Despite the infrequency of studies on this topic, we found that these findings corroborate those of other studies carried out in China, Athens, the United States and Sweden, which revealed a strong association between CVD and negative self-rated health (regular and poor) in adults ${ }^{(15,23)}$. A prospective study found that negative self-rated health is an indicative factor of the occurrence of $\mathrm{CVD}^{(24)}$. Thus, it is noteworthy that self-rated health is directly influenced by lifestyle behaviors, which in turn influence the health condition of the individual.

A study conducted in four countries (Denmark, Finland, Norway, and Sweden) showed that especially bad perception of health association occurs with AMI and HF, confirming the findings of this study because these diseases had greater statistical significance and a larger association represented by $\mathrm{OR}^{(8)}$. Changes in daily life, especially among people with heart failure are evident signs of disease and are related to the sudden perception of the disease, the need to adapt to this condition, a concern with invasive procedures, hospitalization and fear of death. This sharpens self-rated health in the individual because the patient's evaluation of the disease's impact depends on their beliefs and experiences that go with it ${ }^{(25)}$.
With regards to angina for which self-rated health was not associated according to the findings of this study, a difference for older adults of low-income population was observed; they see their health as poor in the presence of this condition, based on the resulting limitations and interference in their daily life ${ }^{(26)}$. The World Health Survey conducted in 2003 in Brazil with subjects 18 years or older found a prevalence self-perception of not good health among women with angina ${ }^{(27)}$, although not significantly associated.

Self-rated health appears in some studies as a strong predictor of fatal and non-fatal cardiovascular events, especially in the adult population ${ }^{(28-29)}$. Along with being a measure centered on the patient, it is easy to obtain and provide real data representing a useful individual and population health indicator for those working in primary care and public health ${ }^{(24,28)}$. The results of this study show the importance of the health team recognizing the significance of the health problem for the individual who experiences it. Because of this significance, living with the disease, the motives of complaint and the demand for care are surpassed by how the individual perceives their health. This may contribute to the development, proposal and implementation of health care strategies, especially nursing centered on the individual, given their characteristics and needs. In addition, poor self-rated health is of prognostic significance in patients with CVD, serving as a high risk factor for diseases such as stroke and myocardial infarction ${ }^{(28)}$.

The results of this study are in line with the importance of self-rated health as a sensitive factor to different health indicators in different contexts. Self-rated health status also indicates the health needs of the population and how each social group understands their health status, and in this scenario, chronic diseases weigh significantly on poor health perception. Thus, in addition to this variable associated with the binding of risk factors for CVD already evidenced in the literature, it was essential to understand the relationship between self-rated health with the different types of CVD present in the adult population. This in turn indicates the contribution of this study to knowledge advancement and nursing care practices to be implemented for people living with chronic CVD, judging by the need of individualized and unique care considering socioeconomic and demographic characteristics and the particular way in which each individual perceives their health.

\section{CONCLUSION}

The results show that the variables of gender, age, marital status, economic status and self-rated health were shown to be separately associated with CVD. However in multivariate analysis, only age and perception remained in association. It was also shown that regular self-rated health was associated with hypertension, and poor self-rated health with heart failure, stroke, and heart attack (acute myocardial infarction).

We conclude that self-rated health in the population may differ according to the presence or absence of CVD and the type of disease. This necessarily implies a different professional approach to individuals living with cardiovas- 
cular disease, as health professionals need to know the perception they have of their health and the way they deal with the disease, and also identify how this entails their self-care, and how the disease affects the context of their lives and their subjectivity, thereby facilitating the management of cases and the prevention of complications.

The direct and significant association between poor selfrated health and the presence of CVD in adults underscores the applicability of this indicator in population surveys and as a marker of health needs, while pointing out the need for future research on other variables that may influence this relationship, such as the presence of comorbidities.
It is therefore considered that this study was innovated in order to capture self-rated health of a population-based sample of adults, which sets it apart from other studies that investigated the association of self-rated health with similar variables but were only conducted within specific populations (elderly, chronic renal failure patients, diabetes, hypertension, etc.). In addition, the study focused on self-rated health of the association to cases of CVD, so that the results highlight the importance of health professionals to use this variable as a marker/indicator of self-care and attitudes that support the prevention of complications.

\section{RESUMO}

Objetivo: Analisar a associação de características sociodemográficas e a autopercepção de saúde com a presença de doenças cardiovasculares e a associação desta autopercepção com o tipo de doença. Método: Estudo transversal, do tipo inquérito populacional, realizado com 1.232 indivíduos com idade entre 20 e 59 anos, de ambos os sexos, residentes na região metropolitana de Maringá-PR. Os dados foram analisados por meio de regressão logística simples e múltipla. Resultados: $\mathrm{Na}$ análise múltipla, a faixa etária e a autopercepção de saúde estiveram associadas a doenças cardiovasculares, e na análise univariada a autopercepção regular de saúde esteve associada à hipertensão arterial, e a ruim, à insuficiência cardíaca, ao acidente vascular cerebral e ao infarto agudo do miocárdio. Conclusão: As diferenças encontradas na associação da autopercepção de saúde com essas doenças podem indicar como indivíduos com determinadas características lidam com as doenças, possibilitando que a assistência à saúde seja mais individualizada e específica.

\section{DESCRITORES}

Doenças Cardiovasculares; Fatores de Risco; Prevalência; Inquéritos Demográficos; Enfermagem.

\section{RESUMEN}

Objetivo: Analizar la asociación entre las características sociodemográficas y la autopercepción de salud con relación a la presencia de enfermedades cardiovasculares y la asociación de esa autopercepción con la clase de enfermedad. Método: Estudio transversal, del tipo encuesta poblacional, llevado a cabo con 1.232 individuos con edades entre 20 y 59 años, de ambos sexos, residentes en la región metropolitana de Maringá-PR. Los datos fueron analizados por medio de regresión logística simple y múltiple. Resultados: En el análisis múltiple, el rango de edad y la autopercepción de salud estuvieron asociados con las enfermedades cardiovasculares, y en el análisis univariado la autopercepción regular de salud estuvo asociada con la hipertensión arterial, y la mala, con la insuficiencia cardiaca, el accidente vascular cerebral y el infarto agudo del miocardio. Conclusión: Las diferencias encontradas en la asociación de la autopercepción de salud con esas enfermedades pueden señalar cómo los individuos con determinadas características manejan las enfermedades, permitiendo que la asistencia a la salud sea más individualizada y específica.

\section{DESCRIPTORES}

Enfermedades Cardiovasculares; Factores de Riesgo; Prevalencia; Encuestas Demográficas; Enfermería.

\section{REFERENCES}

1. Santos JC, Moreira TMM. Risk factors and complications in patients with hypertension/diabetes in a regional health district of northeast Brazil. Rev Esc Enferm USP. 2012;46(5):1125-32

2. Brasil. Ministério da Saúde. Secretaria de Vigilância em Saúde, Departamento de Análise de Situação de Saúde. Plano de ações estratégicas para o enfrentamento das doenças crônicas não transmissíveis (DCNT) no Brasil 2011-2022. Brasília; 2011.

3. Ribeiro AG, Cotta RMM, Ribeiro SMR. The promotion of health and integrated prevention of risk factors for cardiovascular diseases. Ciênc Saúde Coletiva. 2012;17(1):7-17.

4. Muller EM, Aranha SRR, Roza WSS, Gimeno SG. Spatial evolution of cardiovascular mortality in Paraná State, Brazil: 1989-1991 and 2006-2008. Cad Saúde Pública. 2012;28(6):1067-77.

5. Muniz LC, Schneider BC, Silva ICM, Matijasevich A, Santos IS. Accumulated behavioral risk factors for cardiovascular diseases in Southern Brazil. Rev Saúde Pública. 2012;46(3): 534-42.

6. Reichert FF, Loch MR, Capilheira MF. Autopercepção de saúde em adolescentes, adultos e idosos. Ciênc Saúde Coletiva. 2012;17(12):3353-62.

7. Fernandez-Martinez B, Prieto-Flores ME, Forjaz MJ, Fernández-Mayoralas G, Rojo-Pérez F, Martínez-Martín P. Self-perceived health status in older adults: regional and sociodemographic inequalities in Spain. Rev Saúde Pública. 2012;46(2):310-9.

8. Emmelin M, Nafziger NA, Stenlund H, Weinehall L, Wall S. Cardiovascular risk factor burden has a stronger association with self-rated poor health in adults in the US than in Sweden, especially for the lower educated. Scand J Public Health. 2006;34(2):140-9.

9. Pereira JC, Barreto SM, Passos VMA. Perfil de risco cardiovascular e autoavaliação da saúde no Brasil: estudo de base populacional. Rev Panam Salud Publica. 2009;25(6):491-8. 
10. Brasil. Ministério da Saúde; Secretaria de Vigilância em Saúde. Vigitel Brasil 2011: Vigilância de Fatores de Risco e Proteção para Doenças Crônicas por Inquérito Telefônico [Internet]. Brasília; 2012 [citado 2013 jul. 20]. Disponível em: http://www.dive.sc.gov.br/conteudos/ agravos/Dant/VIGITEL-2011.pdf

11. Bezerra PCL, Opitz SP, Kaifman RJ, Muniz PT. Percepção de saúde e fatores associados em adultos: inquérito populacional em Rio Branco, Acre, Brasil, 2007-2008. Cad Saúde Pública. 2011;27(12): 2441-51.

12. Rodrigues AL, Tonella C. Retratos da Região Metropolitana de Maringá: subsídios para a elaboração de políticas públicas participativas. Maringá: EDUEM; 2010.

13. Barros MBA, Francisco PMSB, Zanchetta LM, César CLG. Tendências das desigualdades sociais e demográficas na prevalência de doenças crônicas no Brasil PNAD: 2003- 2008. Ciênc Saúde Coletiva. 2011;16(9):3755-68.

14. Associação Brasileira de Empresas de Pesquisa (ABEP). ABEP 2012. Dados com base no Levantamento Sócio Econômico 2010 - IBOPE [Internet]. São Paulo; 2012 [citado 2014 jun. 27]. Disponível em: http://www.abep.org/novo/Content.aspx?ContentID=301

15. Darviri C, Artemiadis AK, Tigani X, Alexopoulos EC. Lifestyle and self-rated health: a cross-sectional study of 3,601 citizens of Athens, Greece. BMC Public Health [Internet]. 2011 [cited 2013 July 20];11:619. Available from: http://www.biomedcentral.com/1471$2458 / 11 / 619$

16. Hosmer DW, Lemeshow S. Applied logistic regression. New York: Wiley; 2000.

17. Carnelosso ML, Barbosa MA, Porto CC, Silva AS, Carvalho MM, Oliveira ALI. Prevalência de fatores de risco para doenças cardiovasculares na região leste de Goiânia (GO). Ciênc Saúde Coletiva. 2010;15 Supl. 1:1073-80.

18. Muraro AP, Santos DF dos, Rodrigues PRM, Braga JU. Fatores associados à Hipertensão Arterial Sistêmica autorreferida segundo VIGITEL nas 26 capitais brasileiras e no Distrito Federal em 2008. Ciênc Saúde Coletiva. 2013;18(5):1387-98.

19. Agostinho MR, Oliveira MC, Pinto MEB, Balardin GU, Harzheim E. Autopercepção da saúde entre usuários da Atenção Primária em Porto Alegre, RS. Rev Bras Med Fam Comum [Internet]. 2010 [citado 2013 jul. 20];5(17): 9-15. Disponível em: http://www.rbmfc.org.br/index. $\mathrm{php/rbmfc/article/view/175}$

20. Silva DAS, Petroski EL, Peres MA. Prehypertension and hypertension among adults in a metropolitan area in Southern Brazil: populationbased study. Rev Saúde Pública. 2012;46(6):988-98.

21. Joffres M, Falaschetti E, Gillespie C, Robitaille C, Loustalot F, Poulter N, et al. Hypertension prevalence, awareness, treatment and control in national surveys from England, the USA and Canada, and correlation with stroke and ischaemic heart disease mortality: a cross-sectional study. BMJ Open. 2013;3:e003423.

22. Talaei M, Sadeghi M, Mohammadifard N, Shokouh P, Oveisgharan S, Sarrafzadegan N. Incident hypertension and its predictors: the Isfahan Cohort Study. J Hyertens. 2014;32(1):30-8.

23. Haseli-Mashhadi N, Pan A, Ye X, Wang J, Qi Q, Liu Y, et al. Self-Rated Health in middle-aged and elderly Chinese: distribution, determinants and associations with cardio-metabolic risk factors. BMC Public Health [Internet]. 2009 [cited 2013 July 20];9:368. Available from: http:// www.biomedcentral.com/1471-2458/9/368

24. Van der Linde RM, Mavaddat N, Luben R, Brayne C, Simmons RK, Khaw KT, et al. Self-rated health and cardiovascular disease incidence: results from a longitudinal population-based cohort in Norfolk, UK. PLoS One. 2013;8(6):e65290.

25. Rodrigues SLL, Rodrigues RCM, São-João TM, Pavan RBB, Padilha KM, Gallani MC. Impact of the disease: acceptability, ceiling and floor effects and reliability of an instrument on heart failure. Rev Esc Enferm USP. 2013;47(5):1090-7.

26. Silva TR, Menezes PR. Autopercepção de saúde: um estudo com idosos de baixa renda de São Paulo. Rev Med [Internet]. 2007 [citado 2013 jun. 20];86(1):28-38. Disponível em: http://medicina.fm.usp.br/gdc/docs/revistadc_96_p.28-38\%20861.pdf

27. Theme Filha MM, Szwarcwald CL, Souza Junior PRB. Measurements of reported morbidity and interrelationships with health dimensions. Rev Saúde Pública. 2008;42(1):73-81.

28. Venskutonyte L, Brismar K, Öhrvik J, Rydén L, Kjellström B. Self-rated health predicts outcome in patients with type 2 diabetes and myocardial infarction: a DIGAMI 2 quality of life sub-study. Diab Vasc Dis Res. 2013;10(4):361-7.

29. Rutledge T, Linke SE, Johnson BD, Bittner V, Krantz DS, Whittaker KS, et al. Self-rated versus objective health indicators as predictors of major cardiovascular events: the NHLBI-sponsored women's ischemia syndrome evaluation. Psychosom Med. 2010;72(6):549-55. 